\title{
Survey of Florida green turtles for exposure to a disease-associated herpesvirus
}

\author{
Sadie S. Coberley ${ }^{1}$, Lawrence H. Herbst ${ }^{2}$, Llewellyn M. Ehrhart ${ }^{3}$, Dean A. Bagley ${ }^{3}$, \\ Shigetomo Hirama ${ }^{3}$, Elliott R. Jacobson ${ }^{4}$, Paul A. Klein ${ }^{5, *}$ \\ ${ }^{1}$ Interdisciplinary Program in Biomedical Sciences, College of Medicine, University of Florida, Gainesville, Florida 32610, USA \\ ${ }^{2}$ Department of Pathology, Albert Einstein College of Medicine, Bronx, New York 10461, USA \\ ${ }^{3}$ Department of Biology, University of Central Florida, Orlando, Florida 32816, USA \\ ${ }^{4}$ Department of Small Animal Clinical Sciences, College of Veterinary Medicine, University of Florida, Gainesville, \\ Florida 32611, USA \\ ${ }^{5}$ Department of Pathology, Immunology, and Laboratory Medicine, College of Medicine, Box 100275, University of Florida, \\ Gainesville, Florida 32610, USA
}

\begin{abstract}
A recently developed enzyme-linked immunosorbent assay (ELISA) was used to assess exposure of Florida wild green turtles Chelonia mydas to LETV, the herpesvirus associated with lung-eye-trachea disease (LETD). Plasma samples from 329 wild juvenile green turtles netted in the Indian River lagoon, along the Sebastian reef, or in the Trident basin (Indian River and Brevard Counties, Florida) were tested by ELISA for the presence of antibodies to LETV. Plasma samples from 180 wild juvenile green turtles were tested from these study sites to compare the prevalence of antiLETV antibodies. While some plasma samples from each site contained anti-LETV antibodies (confirmed by Western blot analysis), plasma samples collected from the Indian River lagoon had statistically higher optical density values measured in the ELISA. No statistical differences were observed when these same plasma samples were analyzed for changes in the level of anti-LETV antibodies over 3 years $(1997,1998$, and 1999). To explore the relationship between anti-LETV antibodies and fibropapillomatosis (FP), plasma from 133 green turtles scored for fibropapilloma tumor severity were tested by ELISA. There was no correlation between tumor severity and the presence of antibodies against LETV. Additional plasma samples collected from 16 tagged green turtles captured and sampled more than once (recaptures) were also tested to monitor antibody levels to LETV relative to the FP status of individual turtles over time. Again there was no clear relationship between FP tumor status and the presence of antibodies to LETV. Finally, ELISA tests on plasma from 13 nesting female turtles (9 green and 4 loggerhead) revealed high levels of anti-LETV antibodies in 11 individuals, including 2 loggerhead turtles. These results provide strong evidence that wild Florida green turtle populations at these 3 study sites are exposed to LETV or a closely related virus and that loggerhead turtles may be exposed as well. Based on a cutoff optical density value of $0.310,71$ out of the 329 wild Florida green turtles tested were seropositive for LETV antibodies (seroprevalence $=21.6 \%$ ). In addition, no relationship between FP tumor severity or status and the presence of anti-LETV antibodies was found, further supporting the hypothesis that LETV and the FP-associated herpesvirus (FPHV) are separate infections of marine turtles.
\end{abstract}

KEY WORDS: Lung-eye-trachea disease $\cdot$ LETD $\cdot$ LETD-associated herpesvirus $\cdot$ LETV $\cdot$ Green turtle · Chelonia mydas · Chelonian herpesviruses · Antibodies · ELISA

\section{INTRODUCTION}

Several herpesviruses have been associated with diseases in marine turtles. Lung-eye-trachea diseaseassociated herpesvirus (LETV) was originally isolated

(C) Inter-Research $2001 \cdot$ www.int-res.com from maricultured green turtles and is the only marine turtle herpesvirus successfully isolated in pure culture (Jacobson et al. 1986). Lung-eye-trachea disease (LETD) and its associated herpesvirus, LETV, have not been documented in wild green turtles. The fibropapil-

*Corresponding author: E-mail: paklein@ufl.edu 
lomatosis-associated herpesvirus (FPHV) has been detected in $>95 \%$ of fibropapillomas and in all tumor preparations used to experimentally induce fibropapillomatosis (FP) in healthy turtles (Herbst et al. 1999, Lackovich et al. 1999). However, neither LETV nor FPHV has been proven to be the epizootiologic agents of the marine turtle diseases with which they are associated. Transmission studies with LETV have not been performed and, since the FPHV has not yet been isolated in culture, it has not been possible to fulfill Koch's postulates to establish FPHV as the causative agent of FP.

Serological assays can be used to measure antibodies to LETV and FPHV to establish seroepidemiological data for assessing the population exposure to these viruses and their involvement with their respective diseases. Studies of FPHV exposure have been performed by immunodetection of antibodies to FPHV inclusions in formalin-fixed tumor sections and have been limited by the availability of antigen-containing sections for screening populations of marine turtles (Herbst et al. 1998a, Origgi et al. 2000). LETV was tested as a surrogate antigen for FPHV in an immunohistochemistry format and, although plasma from some FP turtles had anti-LETV immunoreactivity, no correlation was found between the presence of anti-FPHV antibodies and reactivity with LETV-infected cells (Origgi et al. 2000). These studies revealed the limitations of immunohistochemistry in differentiating antibody cross-reactivity due to conserved epitopes shared by these 2 marine turtle herpesviruses from coinfection with both viruses. This pointed to the need for serological tests that have higher specificity for a given marine turtle herpesvirus.

An enzyme-linked immunosorbent assay (ELISA) was successfully developed that is highly specific for the detection of anti-LETV antibodies (Coberley et al. 2001). Plasma from a group of captive-reared turtles with and without FP and a group of wild green turtles were used to validate the ELISA and to explore the association between anti-LETV antibodies, anti-FPHV antibodies (detected by immunohistochemistry), and FP disease. In that limited study, no relationship was found between FP status (anti-FPHV antibodies) and reactivity with LETV in the ELISA, indicating that this assay could distinguish exposure to LETV from exposure to FPHV and supporting the hypothesis that these 2 viral infections are independent of one another. The purpose of the current study was to apply the LETVspecific ELISA assay to a large population of freeranging juvenile green turtles at 3 study sites in Florida to assess the exposure of these turtles to LETV. In addition, we investigated further the relationship between FP and LETV antibodies by analyzing the influence of tumor severity and duration of tumor status on the presence of antibodies to LETV.

\section{MATERIALS AND METHODS}

Antigen preparation. Plaque-purified LETV clones 292 and 221 (Coberley et al. 2001) were propagated in terrapene heart cell monolayer cultures (TH-1; ATCC No. CCL 50) and previously described D-1 green turtle cells (Herbst et al. 1998c). Cell lines were grown in Dulbecco's modified Eagle's medium, DMEM/F12, supplemented with $5 \%$ fetal bovine serum (FBS) and antibiotics in vented flasks in a $5 \% \mathrm{CO}_{2}$ humidified incubator at $28^{\circ} \mathrm{C}$. Preparation of antigen has been described previously (Coberley et al. 2001). Briefly, infected monolayers were scraped, freeze/thawed and then sonicated. After low speed centrifugation for clarification, virus pellets were formed by ultracentrifugation at $40000 \times g$ for $1 \mathrm{~h}$ at $4^{\circ} \mathrm{C}$. Virus pellets were washed in phosphate buffered saline (PBS), repelleted, resuspended in PBS, and then sonicated for $60 \mathrm{~s}$. Virus titers were determined by plaque assay as previously described and were approximately $1.0 \times 10^{6} \mathrm{pfu} \mathrm{ml}^{-1}$ (Coberley et al. 2001). Uninfected cells were scraped into medium, pelleted, resuspended in PBS, and sonicated to serve as uninfected cell lysate controls. Protein concentrations of virus and uninfected cell control antigens were measured by Bradford assay protocol and were approximately $1.0 \mathrm{mg}$ protein $\mathrm{ml}^{-1}$ and $3.25 \mathrm{mg} \mathrm{ml}^{-1}$, respectively.

Green turtle plasma samples. A total of 180 plasma samples were obtained from juvenile green turtles netted in the Indian River lagoon (Indian River County, Florida, USA; $27^{\circ} 49^{\prime} 57^{\prime \prime} \mathrm{N}$, 80 $26^{\prime} 18^{\prime \prime} \mathrm{W}$ ), along the reef of the Sebastian Inlet (Indian River County; $27^{\circ} 47^{\prime} 38^{\prime \prime} \mathrm{N}$, $80^{\circ} 24^{\prime} 34^{\prime \prime} \mathrm{W}$ ), or in the Trident Basin (Cape Canaveral, Brevard County, Florida). Blood was drawn from the dorsal cervical sinus and was collected in lithium heparin-treated vacutainer tubes. The blood samples were transported on ice to the laboratory where the samples were then centrifuged at maximum speed in an Adams Physicians Centrifuge (Becton Dickinson, Sparks, MD) for $10 \mathrm{~min}$. Plasma was collected and stored at $-20^{\circ} \mathrm{C}$. Of the 60 plasma samples collected from each study site, 20 were collected in 1997, 1998, and 1999. Plasma samples were selected to prevent sampling an individual turtle at more than 1 location or from more than $1 \mathrm{yr}$. A random number generator was applied to the database blinded for FP status to select 20 plasma samples from each site for each year.

A separate survey tested 133 plasma samples collected from January 1998 to December 1999 from green turtles netted in the Indian River lagoon. These green turtles were scored for fibropapilloma tumor severity (Hirama \& Ehrhart 2000). Green turtles were assigned to a tumor severity score ranging from 0 (no tumor) to 3 (most severe) as previously 
described (Balazs \& Pooley 1991). Plasma samples from green turtles of each tumor severity score were randomly selected from those available in the plasma bank.

Plasma samples collected between 1995 and 1999 from 16 individual wild green turtles captured more than once (recaptures) were also tested by ELISA. Tag numbers allowed individuals to be identified from year-to-year. In addition, plasma collected from a small group of adult nesting female turtles were tested for the presence of antibodies to LETV. Samples from 9 green turtles and 4 loggerhead turtles nesting on Melbourne Beach (Indian River County) were assayed by ELISA. In all assays, plasma from 2 captive reared green turtles, 99C-1 and 99A-1, prior to and after immunization with inactivated LETV served as positive and negative anti-LETV antibody controls (Coberley et al. 2001).

ELISA procedure. The ELISA assay for detecting anti-LETV antibodies has been described (Coberley et al. 2001). Briefly, each well of a 96 flat bottom-well microtiter plate (Nunc-Immuno MaxiSorp, Nunc, Kamstrup, Denmark) was filled with $50 \mu \mathrm{l}$ of LETV or uninfected cell lysate control at a concentration of $5 \mu \mathrm{g}$ protein $\mathrm{ml}^{-1}$, and then covered with sealing tape and incubated overnight at $4^{\circ} \mathrm{C}$. The wells were washed in an automatic plate washer (ELX50, Bio-Tek Instruments, Inc., Winooski, VT) 4 times with $250 \mu \mathrm{l}$ PBS $0.5 \%$ Tween 20 and $0.02 \%$ sodium azide (PBS/T) and then blocked overnight with $5 \%$ w/v non-fat dry milk in PBS/T (PBS/TM) at $4^{\circ} \mathrm{C}$. After washing, $50 \mu \mathrm{l}$ of green turtle plasma samples diluted 1:25 in PBS/TM or LETV-negative or -positive control turtle plasma diluted 1:100 in PBS plus $2 \% \mathrm{v} / \mathrm{v}$ FBS (PBS/F) was added to the appropriate wells. Each plasma sample was incubated with LETV and uninfected cell lysate control for $1 \mathrm{~h}$ at room temperature on a Nutator (Becton Dickinson, Sparks, MD). The microplate was washed and $50 \mu \mathrm{l}$ of biotinylated monoclonal HL858 (anti-green turtle 7s IgG) (Herbst \& Klein 1995) diluted to a concentration of $1 \mu \mathrm{g} \mathrm{ml}^{-1}$ was incubated for $1 \mathrm{~h}$ at room temperature on a Nutator. After washing, $50 \mu$ of alkaline phosphatase-conjugated streptavidin (Zymed Laboratories Inc., San Francisco, CA) diluted 1:5000 in PBS/A was added to each well. The microplate was incubated and washed as described above, and then $100 \mu$ of $p$-nitrophenyl phosphate disodium $\left(1 \mathrm{mg} \mathrm{ml}^{-1}\right.$ in $0.01 \mathrm{M}$ sodium bicarbonate $\mathrm{pH}$ 9.6, $2 \mathrm{mM} \mathrm{MgCl}_{2}$ ) was added to each well. The microplate was incubated in the dark without agitation at room temperature. The $A_{405}$ (absorbance of light at a wavelength of $405 \mathrm{~nm}$ ) of each well was measured after a $2 \mathrm{~h}$ incubation in an ELISA plate reader (Spectra II, SLT-Labinstruments, Salzburg, Austria, with DeltaSoft Version 3.3 software,
Biometallics, Princeton, NJ). Optical density values were adjusted as follows. For each plasma sample, the optical density of the well coated with uninfected cell lysate was subtracted from the optical density of the well coated with virus to account for non-specific absorbance. Optical densities equal to or less than zero were adjusted to 0.001 for statistical analysis. An arbitrary cutoff value was based on optical density values obtained from 42 healthy captive-reared green turtles previously evaluated (Coberley et al. 2001). The cutoff value was calculated as the highest optical density value obtained from healthy captive-reared green turtles plus 3 times the standard deviation (cutoff value = $0.310)$.

Statistical analyses. Statistical analyses were conducted using SigmaStat 2.03 software (SPSS Incorporated, Chicago, IL). The Kolmogorov-Smirnov normality test was applied to optical density value data measured by ELISA. Because many of the groups were non-normally distributed the following statistical analyses were used. The Mann-Whitney rank sum test was used to compare 2 groups. KruskalWallis 1-way ANOVA on ranks was used to compare 3 or more groups. To identify the group or groups that differed from the others, all pairwise multiple comparison procedures were performed using the Tukey test.

Immunoblotting. The specificities of anti-LETV antibodies in selected plasma samples with ELISA optical density values above the cutoff were tested by Western immunoblotting as described previously (Coberley et al. 2001). The LETV and uninfected cell lysate control antigens were separated using polyacrylamide gel electrophoresis (PAGE) under denaturing conditions with a precast $10 \% \mathrm{w} / \mathrm{v}$ polyacrylamide bis-tris gel and MOPS running buffer (NuPAGE, Novex, San Diego, CA). The separated proteins were electroblotted from the gel onto a nitrocellulose membrane, and then the membrane was blocked overnight with PBS/TM at $4^{\circ} \mathrm{C}$. The blocked blot was washed, and then incubated with green turtle plasma at 1:25 dilution in PBS/TM or LETV control plasma diluted 1:100 in PBS/F for $60 \mathrm{~min}$ at room temperature with rocking in a manifold (Pierce, Rockford, IL). After washing, the blot was removed from the manifold and incubated with HL858 as described above for $60 \mathrm{~min}$ at room temperature on a rocker. After washing the membrane, it was incubated in alkaline phosphatase-conjugated streptavidin as described above for $60 \mathrm{~min}$ at room temperature on a rocker. After final washing, the blot was developed in substrate buffer $(0.1 \mathrm{M}$ Tris $\mathrm{HCl} \mathrm{pH} 8.8,1 \mathrm{mM}$ $\mathrm{MgCl}_{2}$ ) containing nitroblue tetrazolium chloride and 5-bromo-4-chloro-3-indolylphosphate $p$-toluidine salt (Promega, Madison, WI). 


\section{RESULTS}

\section{Survey of green turtle populations at three Florida study sites}

Plasma samples from green turtles netted in the Indian River lagoon, along the Sebastian reef, and in Trident Basin were tested for the presence of anti-LETV antibodies by ELISA (Fig. 1). Anti-LETV antibodies were detected in plasma collected from the Indian River lagoon (mean $A_{405}=0.248 ; \mathrm{SE}=0.031 ; \mathrm{n}=60$ ), Sebastian reef (mean $A_{405}=0.167 ; \mathrm{SE}=0.020 ; \mathrm{n}=60$ ) and
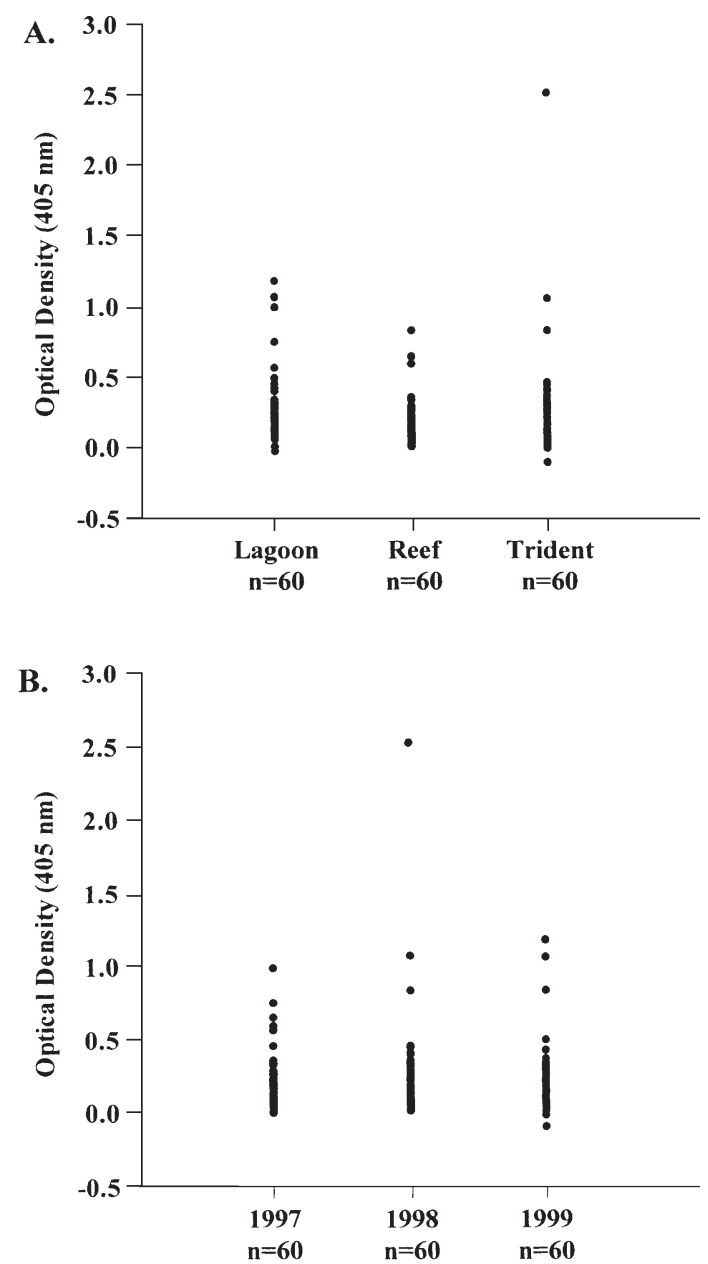

Fig. 1. (A) Measurement of antibodies to LETV by ELISA in plasma samples from juvenile wild green turtles captured in the Indian River lagoon, along the Sebastian reef, or in the Trident basin. (B) Measurement of antibodies to LETV in plasma samples collected from each of the 3 study sites (Indian River lagoon, Sebastian reef, and Trident basin) in 1997, 1998, and 1999. Twenty samples collected from each site in the indicated year were tested. Positive control mean $=1.483$ $\mathrm{SE}=0.057$; negative control mean $=0.016 \mathrm{SE}=0.004 ; 5$ replicates. Plasma from 42 captive-reared turtles with no known exposure to herpesviruses was used for comparison and to select an arbitrary cutoff (optical density value $=0.310$ ) for screening purposes
Trident basin (mean $A_{405}=0.208 ; \mathrm{SE}=0.046 ; \mathrm{n}=60$ (Fig. 1A). All groups were non-normally distributed ( $p \leq 0.002)$. While anti-LETV antibodies were detected in some individuals from all 3 study sites, plasma samples collected from turtles in the Indian River lagoon had statistically higher ELISA values compared to those from the Sebastian reef and Trident basin (Tukey test; $p<0.05)$. The estimated seroprevalence was $21.6 \%$ for the Indian River lagoon, 10\% for the Sebastian reef, and $18.3 \%$ for the Trident basin. Data from each year $(1997,1998,1999)$ at each study site were combined to examine if there was a difference in the level of antiLETV antibodies over time in Florida (Fig. 1B). All groups were non-normally distributed ( $p \leq 0.001$ ). There was no statistical difference in the ELISA values obtained from Florida green turtle plasma samples collected in 1997, 1998 and 1999 (Kruskal-Wallis ANOVA; $\mathrm{p}=0.393 ; \mathrm{n}=60$ per year). The presence of antibodies to LETV in selected plasma samples with ELISA optical density values above the cutoff was confirmed by Western blot analysis (data not shown).

\section{Survey of green turtles scored for FP tumor severity}

To explore the relationship between FP and antiLETV antibodies, plasma from green turtles scored for FP tumor severity were tested (Fig. 2). Antibodies to

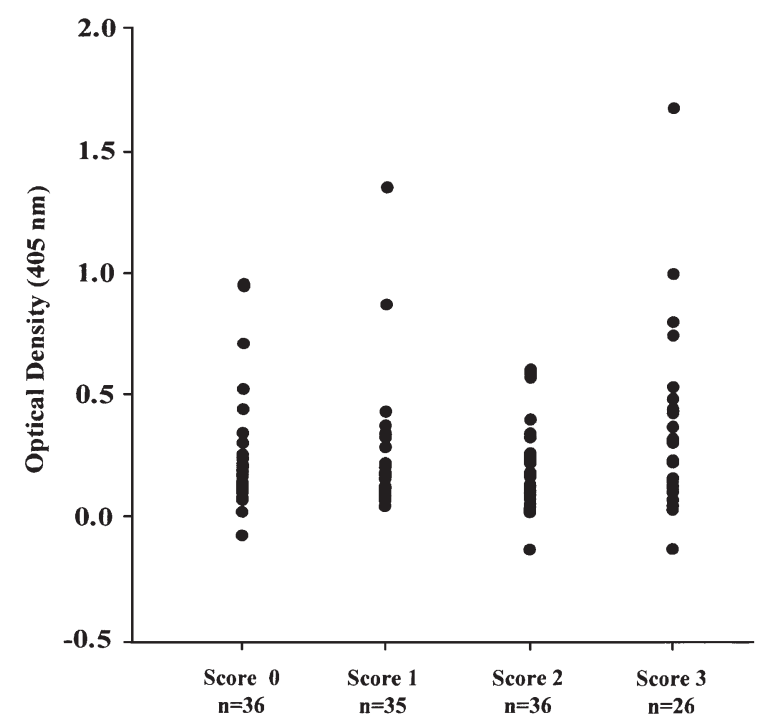

Fig. 2. Measurement of antibodies to LETV by ELISA in plasma from wild green turtles scored for fibropapilloma severity. Plasma from individual turtles in all tumor score categories (score $0=$ no tumor to score $3=$ most severe) contained antibodies to LETV. Positive control mean $=1.423 \mathrm{SE}=$ 0.083 ; negative control mean $=0.004 \mathrm{SE}=0.003 ; 4$ replicates . An arbitrary cutoff of optical density $(\mathrm{OD}=0.310$ ) was used to identify samples positive for antibodies to LETV (see 'Materials and methods') 
LETV were detected by ELISA in the plasma of wild green turtles from score 0 (mean $A_{405}=0.238$; $\mathrm{SE}=$ $0.038 ; \mathrm{n}=36$ ), score 1 (mean $A_{405}=0.228 ; \mathrm{SE}=0.043$; $\mathrm{n}=35)$, score 2 (mean $A_{405}=0.237 ; \mathrm{SE}=0.032 ; \mathrm{n}=36$ ), and score 3 (mean $A_{405}=0.390 ; \mathrm{SE}=0.071 ; \mathrm{n}=26$ ). All groups were non-normally distributed ( $\mathrm{p} \leq 0.010$ ). There was no correlation between FP tumor severity and the presence of antibodies to LETV measured by ELISA (Kruskal-Wallis ANOVA; $p=0.073$ ). The presence of antibodies to LETV in selected plasma samples with ELISA optical density values above the cutoff was confirmed by Western blot analysis (data not shown).

\section{Survey of green turtles recaptured over time}

To examine changes in the level of antibodies to LETV in an individual turtle over time, plasma from green turtles captured more than once (recaptures) were tested by ELISA (Table 1). Plasma samples from turtles at first capture were normally distributed $(\mathrm{p}>$ $0.200)$, but plasma samples from these turtles at last capture were not normally distributed ( $\mathrm{p}<0.001$ ). There was no statistical difference between anti-LETV antibody levels measured by ELISA in plasma collected from an individual turtle the first time captured and the last time captured (Mann-Whitney rank; $T=$ 269.5; $\mathrm{p}=0.851 ; \mathrm{n}=16$ ). Plasma samples from green turtles were divided among the following categories relative to their FP status: FP-positive, FP-negative, regressors (tumor status change from FP-positive to FP-negative), progressors (tumor status change from FP-negative to FP-positive), and other (changing status) (Table 1). There was no clear relationship between FP status and anti-LETV antibody optical density values measured in the ELISA.

\section{Summary of ELISA tests on green turtle plasma samples}

To estimate the seroprevalence of LETV in freeranging juvenile green turtles on the east coast of Florida, optical density values obtained from all plasma samples $(n=329)$ screened by ELISA in this study were combined (Fig. 3). The distribution of ELISA values from plasma of wild green turtles was compared to the distribution of 42 healthy, capturereared juvenile green turtles (mean $A_{405}=0.020$; $\mathrm{SE}=0.006$ ) previously reported (Coberley et al. 2001). Based on the arbitrary cutoff optical density of 0.310 , 71 out of the 329 wild Florida green turtles tested were seropositive for LETV antibodies (seroprevalence = $21.6 \%$ ).
Table 1. Measurement of antibodies to LETV in plasma from individual wild green turtles captured more than once (recaptures). OD: optical density; FP: fibropapillomatosis

\begin{tabular}{|c|c|c|c|c|}
\hline Category & $\begin{array}{l}\text { Turtle } \\
\text { ID no. }\end{array}$ & $\begin{array}{c}\text { Sampling } \\
\text { interval }^{\mathrm{a}}(\mathrm{mo})\end{array}$ & $\begin{array}{c}\text { ELISA } \\
\text { OD }\end{array}$ & $\begin{array}{l}\text { FP } \\
\text { status }^{b}\end{array}$ \\
\hline \multirow[t]{5}{*}{$\begin{array}{l}\text { FP-positive } \\
(\mathrm{n}=5)\end{array}$} & BP4527 & $\begin{array}{r}0 \\
31\end{array}$ & $\begin{array}{l}0.238 \\
0.271\end{array}$ & $\begin{array}{l}+ \\
+\end{array}$ \\
\hline & BP4529 & $\begin{array}{l}0 \\
9\end{array}$ & $\begin{array}{l}0.202 \\
0.185\end{array}$ & $\begin{array}{l}+ \\
+\end{array}$ \\
\hline & BP4567 & $\begin{array}{r}0 \\
25 \\
33\end{array}$ & $\begin{array}{l}0.222 \\
0.145 \\
0.083\end{array}$ & $\begin{array}{l}+ \\
+ \\
+\end{array}$ \\
\hline & BP5648 & $\begin{array}{r}0 \\
15\end{array}$ & $\begin{array}{l}0.278 \\
0.046\end{array}$ & $\begin{array}{l}+ \\
+\end{array}$ \\
\hline & BP5603 & $\begin{array}{r}0 \\
37\end{array}$ & $\begin{array}{l}0.089 \\
0.027\end{array}$ & $\begin{array}{l}+ \\
+\end{array}$ \\
\hline \multirow[t]{5}{*}{$\begin{array}{l}\text { FP-negative } \\
(\mathrm{n}=5)\end{array}$} & BP4572 & $\begin{array}{r}0 \\
31\end{array}$ & $\begin{array}{l}0.060 \\
0.650\end{array}$ & $\begin{array}{l}- \\
-\end{array}$ \\
\hline & BP4595 & $\begin{array}{r}0 \\
33\end{array}$ & $\begin{array}{l}0.347 \\
1.718\end{array}$ & $\begin{array}{l}- \\
-\end{array}$ \\
\hline & BP5622 & $\begin{array}{r}0 \\
42 \\
47\end{array}$ & $\begin{array}{l}0.344 \\
0.218 \\
0.327\end{array}$ & $\begin{array}{l}- \\
- \\
-\end{array}$ \\
\hline & BP5570 & $\begin{array}{r}0 \\
22 \\
29\end{array}$ & $\begin{array}{l}0.429 \\
0.296 \\
0.246\end{array}$ & $\begin{array}{l}- \\
- \\
-\end{array}$ \\
\hline & BР5663 & $\begin{array}{r}0 \\
42\end{array}$ & $\begin{array}{l}0.015 \\
0.223\end{array}$ & $\begin{array}{l}- \\
-\end{array}$ \\
\hline \multirow[t]{3}{*}{$\begin{array}{l}\text { Regressors } \\
(\mathrm{n}=3)\end{array}$} & BP5607 & $\begin{array}{r}0 \\
36\end{array}$ & $\begin{array}{l}0.248 \\
0.160\end{array}$ & $\begin{array}{l}+ \\
-\end{array}$ \\
\hline & BP5635 & $\begin{array}{r}0 \\
25 \\
38\end{array}$ & $\begin{array}{l}0.001 \\
0.001 \\
0.108\end{array}$ & $\begin{array}{l}+ \\
- \\
-\end{array}$ \\
\hline & BР5637 & $\begin{array}{r}0 \\
19 \\
37\end{array}$ & $\begin{array}{l}0.857 \\
0.003 \\
0.181\end{array}$ & $\begin{array}{l}+ \\
- \\
-\end{array}$ \\
\hline \multirow[t]{2}{*}{$\begin{array}{l}\text { Progressors } \\
(\mathrm{n}=2)\end{array}$} & BP6641 & $\begin{array}{r}0 \\
18\end{array}$ & $\begin{array}{l}0.026 \\
0.015\end{array}$ & $\begin{array}{l}- \\
+\end{array}$ \\
\hline & BР7397 & $\begin{array}{r}0 \\
31\end{array}$ & $\begin{array}{l}0.173 \\
0.062\end{array}$ & $\begin{array}{l}- \\
+\end{array}$ \\
\hline $\begin{array}{l}\text { Other } \\
(\mathrm{n}=1)\end{array}$ & BP3295 & $\begin{array}{r}0 \\
6 \\
11\end{array}$ & $\begin{array}{l}0.001 \\
0.001 \\
0.025\end{array}$ & $\begin{array}{l}- \\
+ \\
-\end{array}$ \\
\hline
\end{tabular}

\section{Survey of adult nesting female turtles}

Plasma from adult nesting females were tested for the presence of anti-LETV antibodies by ELISA. Antibodies to LETV were detected in plasma of both green (mean $A_{405}=2.114, \mathrm{SE}=0.356, \mathrm{n}=9$ ) and loggerhead turtles (mean $A_{405}=1.614, \mathrm{SE}=0.787, \mathrm{n}=4$ ) (Fig. 4) 


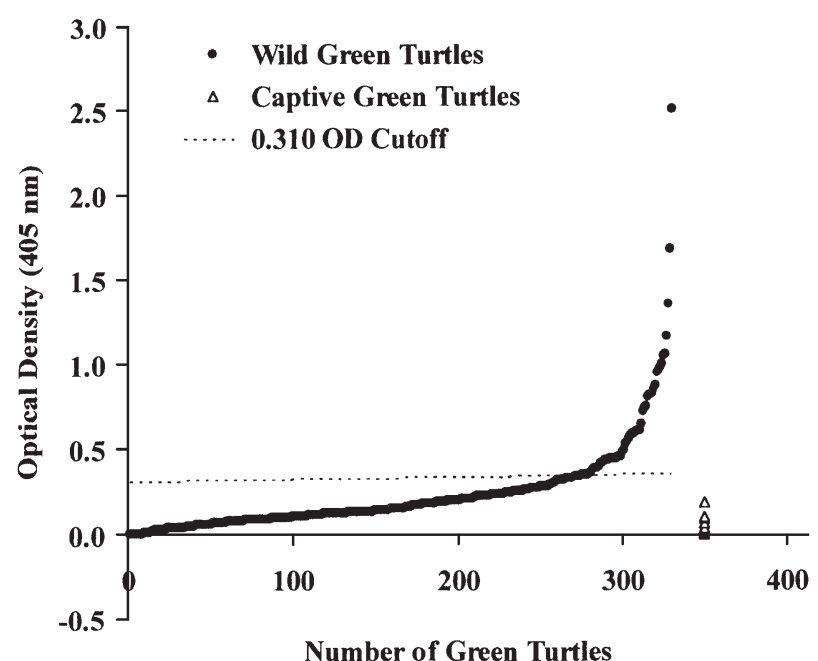

Fig. 3. Summary of ELISA measurements for antibodies to LETV in plasma from 329 Florida wild green turtles. An arbitrary cutoff of optical density $(O D=0.310)$ was used to identify samples positive for antibodies to LETV (see 'Materials and methods')

The green and loggerhead plasma samples with the ELISA optical density values above the cutoff were tested by Western blot (Fig. 5). Plasma samples reacted with proteins in the LETV-infected cell lysates not present in the uninfected cell lysate controls. Many of the protein bands in LETV-infected lysates were also

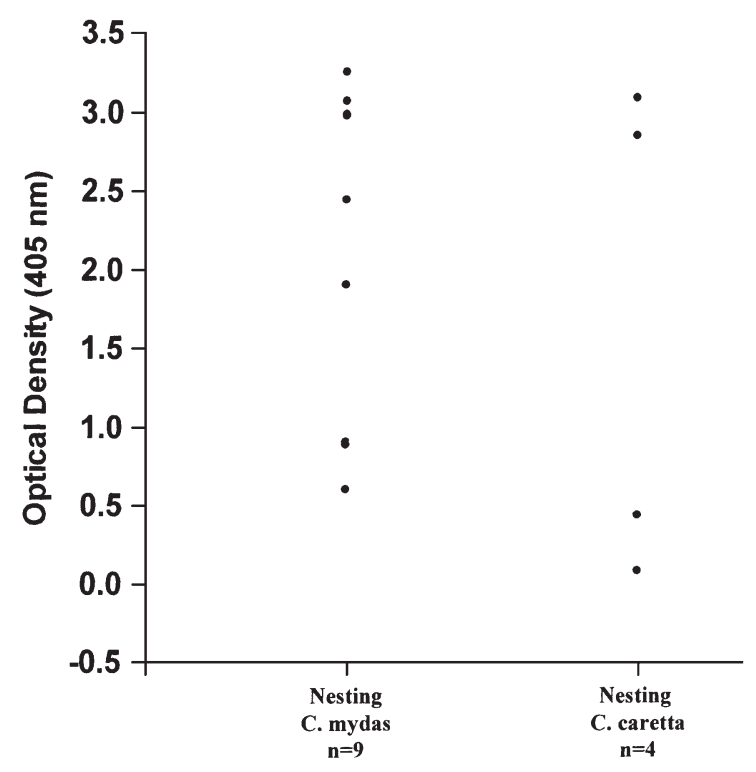

Fig. 4. Detection of antibodies to LETV by ELISA in plasma from nesting green and loggerhead turtles (Chelonia mydas and $C$. caretta, respectively). Positive control 1.144; $\mathrm{SE}=$ 0.094 ; negative control $0.014 \mathrm{SE}=0.004 ; 2$ replicates. An arbitrary cutoff of optical density (OD $=0.310$ ) was used to identify samples as positive for antibodies to LETV (see 'Materials and methods') recognized by anti-LETV antibodies in the plasma of other free-ranging (non-nesting) turtles (Coberley et al. unpubl.) and turtles immunized with inactivated LETV (positive control; Fig. 5B: Lane 3). The 19 and $38 \mathrm{kDa}$ proteins were recognized most consistently by green turtle antibodies to LETV in these studies.

\section{DISCUSSION}

The ability to grow LETV in culture has facilitated the development of an ELISA to assess exposure of populations of wild turtles to this herpesvirus. In this study, the LETV-specific ELISA successfully detected antibodies to LETV in plasma samples collected from 329 wild green turtles at 3 study sites on the east coast of Florida (estimated seroprevalence of $21.6 \%$ ).

Antibodies to LETV were detected in the plasma of some green turtles at each study site: the Indian River lagoon, the Sebastian reef, and the Trident basin. Interestingly, the estimated seroprevalence and levels of anti-LETV antibodies were slightly higher for green turtles in the Indian River lagoon (Fig. 1A). It is known that, compared to other nearby sites, green turtles in the Indian River lagoon have a higher prevalence of fibropapillomatosis, which is associated with the herpesvirus, FPHV (Lackovich et al. 1999). For example in 1998, a survey of green turtles in the Indian River lagoon showed a FP prevalence of $72.5 \%$ (L. Ehrhart pers. comm.) compared to the Trident basin, where FP has never been documented (D. Bagley pers. comm.). These data suggest that conditions in the Indian River lagoon may facilitate the transmission of infectious diseases and even increase disease severity. These factors may include the presence of vectors for transmission, the presence of virus-stabilizing conditions, and favorable water temperature (Herbst \& Klein 1995, Curry et al. 2000).

There was no obvious change in LETV antibody levels in the samples tested over a 3 yr study period, suggesting that LETV exposure, in general, was not increasing (Fig. 1B). This was further supported by data obtained from ELISA assays of plasma from recaptured individuals tested over time (1995 to 1999). There was no statistical change in optical density values to LETV from the first time a turtle was captured compared to last time it was captured (Table 1). Thus LETV is not likely to represent a new epizootic at these sites but may instead be part of an endemic or sporadic infection. This is similar to the pattern of endemic herpesvirus infections in other vertebrates (Fields et al. 1996).

There appears to be no relationship between FP tumor severity or status and the presence of anti-LETV antibodies as detected by ELISA. Antibody optical 


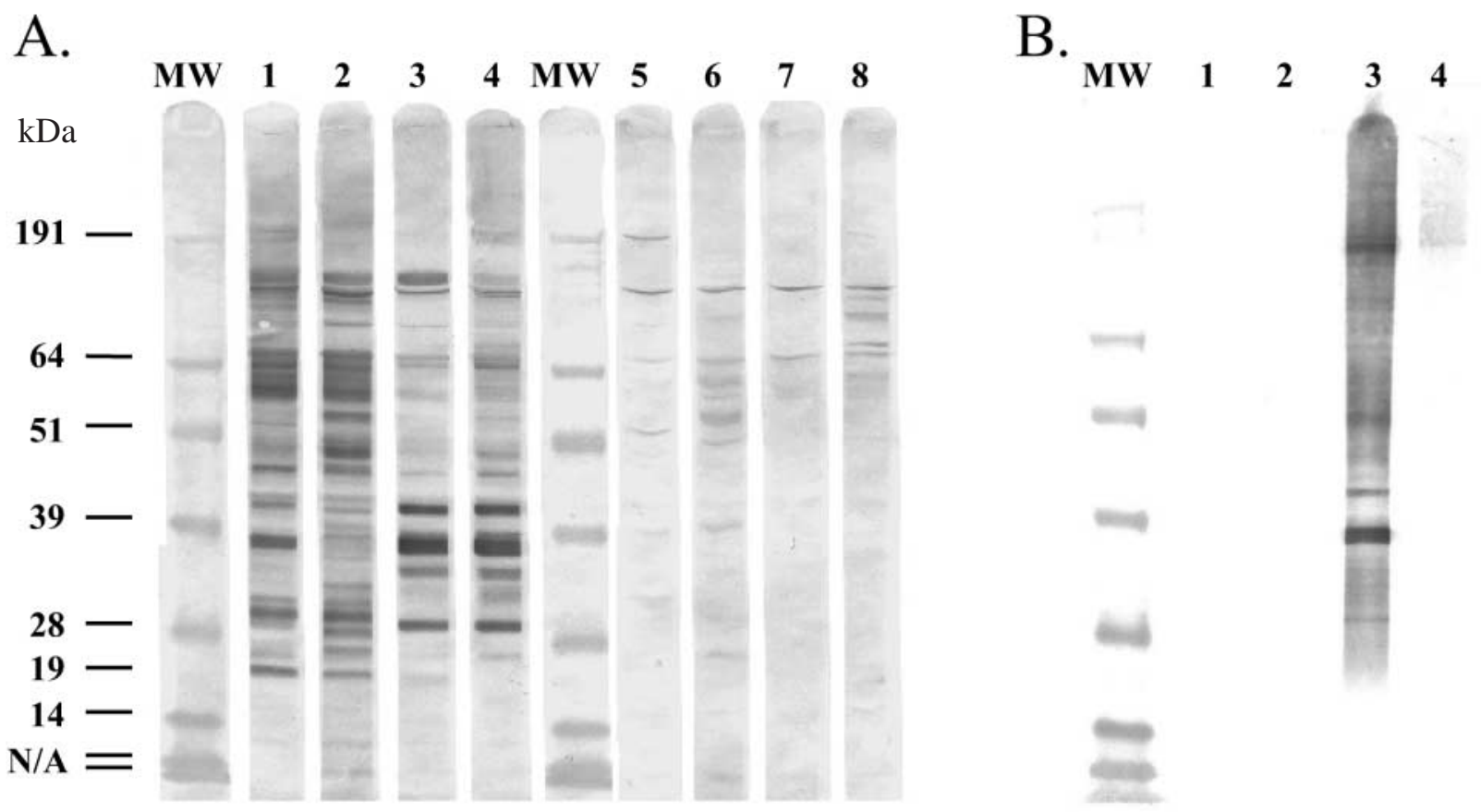

Fig. 5. (A) Western blot confirms the presence of antibodies to LETV in selected plasma samples from nesting green and loggerhead turtles with ELISA values above the cutoff optical density $(\mathrm{OD}=0.310)$. LETV $(10 \mu \mathrm{g})$ was used as antigen in Lanes $1-4$; cell lysate $(10 \mu \mathrm{g})$ used as control antigen in Lanes 5-8. Lanes 1 and 5: P2840 green turtle plasma; Lanes 2 and 6: N6385 green turtle plasma; Lanes 3 and 7: N9897 loggerhead turtle plasma; Lanes 4 and 8: N9954 loggerhead turtle plasma. MW, molecular weight marker. (B) Western blot incubated with control plasma. LETV (10 $\mu \mathrm{g})$ was used as antigen in Lanes 1 and 3; cell lysate (10 $\mu \mathrm{g})$ was used as antigen in Lanes 2 and 4. Lanes 1 and 2: negative control plasma; Lanes 3 and 4: positive control plasma

density values were similar in all tumor severity score categories (Fig. 2). Although score 3 category optical density values were slightly higher on average, the 2 extremes, score 0 (no tumor) to score 3 (most severe FP), were not statistically different from each other. One concern when testing for the presence of LETV antibodies and the association of LETV exposure with FP is that while a tumor may be grossly visible, the turtle may not yet have mounted a detectable immune response to the virus. It is assumed that a turtle with a tumor severity score of 3 is in the advanced stage of the disease, has been afflicted with FP for a prolonged duration, and would have ample time to develop an anti-FPHV antibody response capable of cross-reacting with LETV or to develop an anti-LETV response if LETV was associated with the disease, FP. It is known that green turtles with experimentally induced fibropapillomatosis develop detectable antibody responses to FPHV within $1 \mathrm{yr}$ post inoculation (Herbst et al. 1995), suggesting that a wild turtle with a tumor for a year or more would likely have mounted an immune response to the etiologic agent. It was shown that turtles with FP for up to 3 yr had very low optical density values to LETV (for example, Table 1; BP5603), again supporting the hypothesis that it is unlikely that LETV has a role in FP. Instead, detection of antibodies to
LETV in an FP-positive turtle is likely due to coinfection with LETV or a LETV-like virus.

In this study, the seroprevalence of LETV in juvenile wild green turtles in Florida was estimated to be $21.6 \%$ (Fig. 3). For screening purposes, an arbitrary optical density cutoff value of 0.310 was used for this study based on 42 healthy captive-reared green turtles with no known exposure to herpesviruses (Coberley et al. 2001). Currently, it is difficult to define accurately the seroprevalence of LETV in marine turtle populations using this ELISA alone (Coberley et al. 2001). Additional positive plasma samples from LETV-exposed wild turtles are needed to better describe the distribution of the known seropositive population since the range of ELISA values where the seropositive and seronegative populations overlap guides the selection of a cutoff value (Crowther 2001).

Preliminary examination of plasma collected from 13 nesting green and loggerhead turtles revealed the highest optical densities measured to LETV by ELISA. The seroprevalence in this small sample was $100 \%$ for the green and $75 \%$ for the loggerhead nesting turtles and the presence of anti-LETV antibodies was confirmed by Western blot. The implications of this data for turtle populations are unknown at this time, but suggest widespread exposure. One possibility is that 
as an adult turtle, nesting females have a constant high level of antibodies to LETV. This would be similar to human and other mammals in which titers to herpesviruses persist for their lifetime (Fields et al. 1996, Hoang et al. 1999, Collier \& Oxford 2000). For example, $>95 \%$ of the adult human population have relatively high levels of antibodies to varicella-zoster virus, human herpesvirus 6 and 7, and Epstein-Barr virus as a result of chronic exposure and latent infection with these herpesviruses throughout their lifetimes (Hoang et al. 1999). If this were the case for turtles, then an estimated seroprevalence of $21.6 \%$ in juveniles would indicate that at this life stage marine turtles are at the beginning of their exposure to LETV, and as the turtle population ages seroprevalence would increase. Another possibility is that the stress or hormonal changes associated with nesting causes recrudescence of virus shedding in infected females causing a 'booster' effect on the antibody titer. Alternatively, it may be that prior to nesting there may be a hormone-mediated increase in antibody levels to the entire spectrum of antigens/ pathogens that turtles have encountered in their lifetime in preparation for vertical transfer of these antibodies to offspring through the egg. Because all of the adult samples are from nesting females a hormonal effect or sex differences cannot be ruled out and require further study. However, one nesting loggerhead turtle had a low optical density reading for LETV (Fig. 4), suggesting that not all adult females may have been exposed, and that elevated antibody levels are specific for LETV and may not reflect a generalized polyclonal activation of antibody synthesis prior to nesting. Currently, the sample size is small and it is not known if this is an accurate representation of the adult population. Future collaborations will work to increase the plasma sample size from nesting and non-nesting females and to begin to collect plasma from adult males to better assess exposure to LETV.

Several adult nesting female loggerhead turtles had high levels of antibodies to LETV. This is the first data to suggest that loggerheads in Florida may also be infected with LETV or a LETV-like herpesvirus. This finding is not surprising since the closely related FPHV virus is associated with FP in green, loggerhead, and olive ridley turtles (Jacobson et al. 1991, Herbst et al. 1998b, Quackenbush et al. 1998, Lackovich et al. 1999). The ELISA should be applied to assess exposure of other turtle species to LETV.

Western blot analysis of green turtle plasma samples with ELISA optical density values above the cutoff were used to confirm the presence of anti-LETV antibodies in this study (Fig. 5). Western blot analysis revealed several virus-specific bands of interest in the LETV-infected cells. Future studies will focus on the identification of several of these viral antigens, in par- ticular the 19 and $38 \mathrm{kDa}$ proteins. Some of these antigens may be useful for the development and refinement of new serological tests for other sea turtle herpesviruses.

While antibodies were detected in plasma from green turtles at the current study sites in Florida, clinical signs of disease have not been documented. In captivity, disease is documented in 1 yr old hatchlings (Jacobson et al. 1986). This life stage of free-ranging turtles is pelagic and is not frequently witnessed by researchers and turtle biologists (Jacobson et al. 1986). In addition, factors or stresses that influence viral pathogenesis or influence disease severity in a mariculture system may not be present in natural marine environments (Haines \& Kleese 1977, Collier \& Oxford 2000). It may be that infection with LETV in wild populations are subclinical and rarely exhibit the clinical severity demonstrated in mariculture unless turtles are stressed or debilitated.

The application of the LETV-specific ELISA has allowed documentation of the presence and prevalence of antibodies to LETV in wild Florida marine turtles and has provided evidence for the occurrence of infection in these populations. Future research will explore the impact LETV may have on marine turtle populations and will investigate the relationship between LETV and LETD. Further studies like this are needed to enhance the application of seroepidemiological approaches to establish cause-effect disease relationships in marine turtles exposed to other herpesviruses, including FPHV.

Acknowledgements. This research was supported by research grants RWO 180 and RWO 194 from the US Fish and Wildlife Service, Department of the Interior administered by the Cooperative Fish and Wildlife Unit, University of Florida, Gainesville, Florida.

\section{LITERATURE CITED}

Balazs GH, Pooley SG (1991) Research plan for marine turtle fibropapilloma. US Dept Commerce, NOAA Tech Memo NMFS-SEFSC-156

Coberley SS, Herbst LH, Brown DR, Ehrhart LM and 5 others (2001) Detection of antibodies to a disease-associated herpesvirus of the green turtle, Chelonia mydas. J Clin Micro 39(10):3572-3577

Collier L, Oxford J (2000) Human virology, 2nd edn. Oxford University Press, New York, NY

Crowther JR (2001) Methods in molecular biology. In: The ELISA guidebook. Humana Press, Totowa, NJ, p 301-326

Curry SS, Brown DR, Gaskin JM, Jacobson ER and 4 others (2000) Persistent infectivity of a disease-associated herpesvirus in green turtles after exposure to seawater. J Wildl Dis 36:792-797

Fields BN, Knipe DM, Howley PM (1996) Fields virology, 3rd edn. Lippincott-Raven Publishers, Philadelphia, PA 
Haines H, Kleese W (1977) Effect of water temperature on a herpesvirus infection of sea turtles. Infect Immun 15(3): $756-759$

Herbst LH, Klein PA (1995) Monoclonal antibodies for the measurement of class specific antibody responses in the green turtle, Chelonia mydas. Vet Immunol Immunopathol 46:317-335

Herbst LH, Jacobson ER, Moretti R, Brown T, Sundberg JP, Klein PA (1995) Experimental transmission of green turtle fibropapillomatosis using cell-free tumor extracts. Dis Aquat Org 22:1-12

Herbst LH, Greiner EC, Ehrhart LM, Bagley DA, Klein PA (1998a) Serological association between spirorchidiasis, herpesvirus infection, and fibropapillomatosis in green turtles from Florida. J Wildl Dis 34:496-507

Herbst LH, Garber RL, Lockwood L, Klein PA (1998b) Molecular biological evidence for the involvement of a unique herpesvirus in the pathogenesis of green turtle fibropapillomatosis. In: Proceedings of the Sixteenth Annual Symposium on Sea Turtle Biology and Conservation. US Dept Commerce, NOAA Tech Memo NMFS-SEFSC412

Herbst LH, Sundberg JP, Shultz LD, Gray BA, Klein PA (1998c) Tumorigenicity of green turtle fibropapillomaderived fibroblast lines in immunodeficient mice. Lab Anim Sci 48:162-167

Herbst LH, Jacobson ER, Klein PA, Balazs GH, Moretti R, Brown T, Sundberg JP (1999) Comparative pathology and pathogenesis of spontaneous and experimentally induced fibropapillomas of green turtles (Chelonia mydas). Vet Pathol 36:551-564

Editorial responsibility: Peernel Zwart,

Utrecht, The Netherlands
Hirama S, Ehrhart LM (2000) Epizootiology of green turtle fibropapillomatosis on the Florida Atlantic coast (USA). In: Proceedings of the Twentieth Annual Symposium on Sea Turtle Biology and Conservation. US Dept Commerce, NOAA Tech Memo NMFS-SEFSC (in press)

Hoang MP, Rogers BB, Dawson BD, Scheuermann RH (1999) Quantitation of 8 human herpesviruses in peripheral blood human immunodeficiency virus-infected patients and healthy blood donors by polymerase chain reaction. Am J Clin Pathol 111:655-659

Jacobson ER, Gaskin JM, Roelke M, Greiner EC, Allen J (1986) Conjunctivitis, tracheitis, and pneumonia associated with herpesvirus infection in green sea turtles. J Am Vet Med Assoc 189:1020-1023

Jacobson ER, Harris RK, Buergelt C, Williams B (1991) Herpesvirus in cutaneous fibropapillomas of the green turtle Chelonia mydas. Dis Aquat Org 12:1-16

Lackovich JK, Brown DR, Homer BL, Garber RL and 8 others (1999) Association of herpesvirus with fibropapillomatosis of the green turtle Chelonia mydas and the loggerhead turtle Caretta caretta in Florida. Dis Aquat Org 37:89-97

Origgi FC, Jacobson ER, Herbst LH, Klein PA, Curry SS (2000) Development of serological assays for herpesvirus infections in chelonians. In: Proceedings of the Twentieth Annual Symposium on Sea Turtle Biology and Conservation. US Dept Commerce, NOAA Tech Memo NMFSSEFSC (in press)

Quackenbush SL, Work TM, Balazs GH, Casey RN and 7 others (1998) Three closely related herpesviruses are associated with fibropapillomatosis in marine turtles. Virology 246:392-399

Submitted: May 6, 2001; Accepted: July 9, 2001

Proofs received from author(s): November 20, 2001 